\title{
P-cadherin expression and survival rate in oral squamous cell carcinoma:an immunohistochemical study
} Lorenzo Lo Muzio1, Giuseppina Campisi*2, Antonio Farina3, Corrado Rubini ${ }^{4}$, Giuseppe Pannone ${ }^{1}$, Rosario Serpico ${ }^{5}$, Gregorio Laino ${ }^{1}$, Alfredo De Lillo $^{1}$ and Francesco Carinci ${ }^{6}$

\author{
Address: ${ }^{1}$ Department of Surgical Sciences, University of Foggia, Foggia, Italy, ${ }^{2}$ Department of Dental Sciences "G. Messina", University of Palermo, \\ Palermo, Italy, ${ }^{3}$ Institute of Histology, University of Bologna, Bologna, Italy, ${ }^{4}$ Institute of Pathology, University of Ancona, Ancona, Italy, \\ ${ }^{5}$ Department of Dental Sciences, Second University of Naples, Naples, Italy and 'Institute of Maxillofacial Surgery, University of Ferrara, Ferrara, \\ Italy \\ Email: Lorenzo Lo Muzio - llomuzio@tin.it; Giuseppina Campisi* - campisi@odonto.unipa.it; Antonio Farina - crc@unife.it; \\ Corrado Rubini - c.rubini@univpm.it; Giuseppe Pannone - r.serpico@doc.uniba.it; Rosario Serpico - llomuzio@tin.it; \\ Gregorio Laino - gregorio.laino@unina.it; Alfredo De Lillo - crc@unife.it; Francesco Carinci - promoge@odonto.unipa.it \\ * Corresponding author
}

Published: 21 June 2005

BMC Cancer 2005, 5:63 doi:10.1 |86/147|-2407-5-63
Received: 02 January 2005

Accepted: 21 June 2005

This article is available from: http://www.biomedcentral.com/147/-2407/5/63

(c) 2005 Lo Muzio et al; licensee BioMed Central Ltd.

This is an Open Access article distributed under the terms of the Creative Commons Attribution License (http://creativecommons.org/licenses/by/2.0), which permits unrestricted use, distribution, and reproduction in any medium, provided the original work is properly cited.

\begin{abstract}
Background: P-cadherin (P-cad) is a transmembrane molecule involved in the cell-cell adhesion and similar to $\mathrm{E}$-cadherin (E-cad), but less investigated in oncology, especially in in vivo studies. Aims of the present study were to assess the prevalence of P-cad expression in oral squamous cell carcinoma (OSCC) and to verify whether $\mathrm{P}$-cad can be considered a marker of prognosis in patients with OSCC.
\end{abstract}

Methods: In a retrospective study, a cohort of 67 OSCC patients was investigated for P-cad expression and its cellular localization by immunohistochemistry; some respective healthy margins of resection were similarly investigated as standard controls. After grouping for P-cad expression, OSCCs were statistically analyzed for the variables age, gender, histological grading (G), TNM, Staging, and overall survival rate. Univariate and multivariate analyses were performed.

Results: 37 cases (55.2\%) of OSCC showed membranous/cytoplasmic positivity for P-cad, whereas 30 (44.8\%) were negative. Although with some differences in membranous vs cytoplasmic localization of P-cad in OSCC with different G, no statistical association was found between P-cad expression and any variables considered at baseline. In terms of prognostic significance, $P$-cad non expression was found to have an independent association with poorer overall survival rate than $\mathrm{P}$ cad expressing group $(P=0.056)$; moreover, among $P$-cad +ve patients the best prognosis was for those OSCC with membranous $(\mathrm{P}<0.000 \mathrm{I})$ than those with cytoplasmic $\mathrm{P}$-cad expression.

Conclusion: On the basis of these results, it is possible to suggest $\mathrm{P}$-cad as an early marker of poor prognosis. The abnormal or lack of P-cad expression could constitute an hallmark of aggressive biological behavior in OSCC 


\section{Background}

Invasive OSCC, in spite of improved therapeutic procedures, actually show a generally poor prognosis since its local aggressiveness and metastases. In particular, the incidence of lymph node metastases has been found to be significantly associated with several factors; among these, not only macroscopic parameters, such as clinical stage, localization and thickness of primary tumours [1-10], but also microscopic-molecular parameters from differentiation of tumoral cells up to their skill for adherence [1114]. Recently, many investigations have been performed in this latter direction, until to know that intercellular adhesiveness is mediated by a family of glycoproteins named cadherins [15]. This family is composed of an extra-cellular domain, involved in $\mathrm{Ca}^{++}$-dependent homophilic binding to adjacent cells, a trans-membrane domain, and an intra-cellular domain which binds to proteins called catenins [16]. In epithelial cells, this adhesiveness is mediated by epithelial-cadherin (E-cad), a 120-kd transmenbrane glycoprotein, localized mainly in the zonula adherens junctions. The cadherin family includes also other members: neural-cadherin (N-cadherin) [17], placental cadherin (P-cad) [18] and liver cell adhesion molecule (L-CAM), and more than 20 cadherins have been described in the central nervous system, liver and vascular endothelial cells and in other tissues and organs $[19,20]$. In particular, P-cad is a protein homologous to Ecad. E-cadherin is involved in the adherens type of intercellular junctions of keratinocytes, while P-cad is detected on the cell-cell contact surface of basal keratinocytes in normal mouse and human epidermis and cells migrating into the suprabasal compartiment down-regulate P-cad expression. Both these molecules interact with cytoskeleton by alpha-catenin.

P-cad is expressed in mouse placenta [18], epithelia [21], the basal cell of the skin [22,23], playing an important role in the morphogenesis of epidermis and skin appendage $[22,24,25]$. The expression of P-cad in epithelial tissues appears to identify cell populations with proliferative activity, and its expression decreases as cells differentiate $[23,26]$.

The possible role exerted by cadherins in human carcinogenesis has been suggested by a number of studies $[27,28]$. Down-regulation of E-cad was reported to be directly related to invasiveness and progression of many human epithelial tumours [28], including oral squamous cell carcinomas (OSCC) [29].

While E-cad expression has been extensively studied in many forms of human cancers, including OSCC [27,3040], less is known about the expression levels of P-cad in human cancers [23,41-51] and, particularly, in OSCCs in vivo $[35,39,40,52]$.
Aims of the present study were to assess the prevalence of P-cad expression in oral squamous cell carcinoma (OSCC) and to verify whether P-cad can be considered a marker of prognosis in patients with OSCC.

\section{Methods}

Sixty-seven patients affected by histologically proven OSCC were consecutively recruited among those surgically treated in a multicentric study between January 1992 and December 1997. The patients, never treated before for OSCC, included 45 males (67.2\%) and 22 females $(32.8 \%)$. They ranged in age from 18 to 87 years (median age 65 years) at the time of admission; 20 (29.8\%) had neck nodes, and none had evidence of distant metastases. Tumours were classified according to U.I.C.C. 2000 classification (UICC 2000), reaching to the following Stage Grouping: Stage I for 30 OSCC, II for 15, III for 11 and IV for 11 .

Although recruited in different centres, all of OSCCs were treated according to the common and current Guidelines dedicated[53]. In particular, surgery on $\mathrm{T}$ was the treatment of choice and always performed at the initial course of the protocol with curative intent (i.e. only tumour resections in safe margins were done). When radiotherapy was considered useful, it was usually done 3 weeks after surgery, with external beam and the dose was equivalent to 60 or 65 Gy in 6 or 7 weeks. Chemotherapy, when prescribed, consisted of cisplatin $\left(100 \mathrm{mg} / \mathrm{m}^{2}\right.$ body-surface area) given as intravenous infusion followed by continuous 24-hour intravenous infusion of fluorouracil $(1,000$ $\mathrm{mg} / \mathrm{m}^{2}$ per day) for five days. globally up to 3 cycles. All patients were followed up and examined on a monthly basis for the first year after treatment, every 2 months for the second year, and every 3 months thereafter. At our baseline, an overall disease-specific survival was calculated at 72 months for all patients plus cases censored (for death).

\section{Immunohistochemistry}

$5 \mu \mathrm{m}$ serial sections from routinely formalin-fixed paraffin-embedded blocks were cut for each case, and one section stained with haematoxylin-eosin (H.E.) was used to confirm the histopathological diagnosis. Only sections showing sufficient epithelium to assess 1000 cells were considered for this study. In addition, some microscopically healthy specimens of oral mucosa from juxtaposed sites to OSCC went to similar investigation as standard controls.

Immunocytochemistry was then performed on the remaining sections mounted on poly-L-lysine-coated glass slides. Endogenous peroxidase was quenched by incubating the sections for 20 minutes with $0,3 \%$ hydrogen peroxide in methanol. To improve the staining 
pattern, the sections were boiled three times for 3 minutes in $10 \mathrm{mM}$ citrate buffer as an antigen retrieval method. In order to prevent non-specific binding of antibodies, sections were then pre-incubated with non-immune mouse serum (1:20; Dakopatts, Hamburg, Germany) and diluted in PBS/BSA (1\%) for 25 minutes at room temperature. After washing twice with Tris-HCl buffer, primary antibodies were applied. As positive controls, the immunoreactivity of 5 normal skin sections from leg was evaluated. A negative control was also performed in each run by substituting primary antibodies with non-immune serum (DAKO Antibody Diluent, Dakopatts, Hamburg, Germany). All the slides were washed twice in Tris-HCl buffer between each step. Commercially available mouse monoclonal IgG antibody against P-cad (Transduction Laboratories, Lexington, Kentucky, U.S.A.), packaged at $0.25 \mathrm{mg} /$ $\mathrm{ml}$, was used at a dilution of 1:300. Then two methods were applied: Labeled streptavidin-biotin-peroxidase technique (LSAB-HRP) and Labeled Streptavidin-biotinalkaline phosphatase technique (LSAB-AP). In LSAB-HRP technique sequential 20-minute incubation with biotinylated linking antibody and horseradish peroxidaselabeled streptavidin (Dako LSAB + kit, HRP) were performed at room temperature. The peroxidase activity was developed by incubation with 3.3'-diaminobenzidine (DAB, Vector Laboratories, Burlinghame, USA) as a substrate chromogen solution. The slides were then counterstained with hematoxylin. In LSAB-AP technique sequential 20-minute incubations with biotinylated antimouse immunoglogulins and streptavidin conjugated to alkaline phosphatase were performed. Finally, a new fast red substrate system (K0597, Dako, Glostrup, Denmark) was applied as a chromogen solution. The specificity of this antibody has been described in the literature [42].

\section{Evaluation of immunostaining}

The number of P-cad-expressing tumour cells was estimated as a percentage of the final number of 500 neoplastic cells of each case, and scored in two categories: score 0 ( $\leq 5 \%$ of cells were positive), score 1 ( $P$-cad expression in $>5$ of cells \%). The expansion of P-cad-positive cells in the spinous layer was defined as anomalous P-cad expression [47].

\section{Statistical analysis}

Univariate analysis

Differences between P-cad expression values and the variables considered were analysed by means of Student-Newmann-Keuls' test (simple or in multiple comparison) and by ANOVA. The difference was considered significant when $\mathrm{p}$-value was $\geq 0.05$. Disease-specific survival curves were calculated according to the product-limit method (Kaplan-Meier algorithm). Time zero was defined as the date of the patient's initial diagnosis. Patients who are still alive were included in the total number at risk of death only up to the time of their last follow-up. Therefore, the survival rate only changed when death occurred. Patients dead during the follow-up period (i.e. 72 months) were considered as censored. The calculated survival rate was the maximum estimate of the true survival curve. Log rank test was used to compare survival curves, generated by stratifications for a variable of interest.

\section{Cox regression analysis}

Afterwards, Cox regression analysis was applied to determine the single contribution of covariates on survival rate. Cox regression analysis compares survival data while taking into account the statistical value of independent variables, such as age and sex, on whether or not an event (i.e. death) is likely occur. If the associated probability was less then $5 \%$ ( $\mathrm{p}<.05)$, the difference was considered statistically significant. In the process of doing the regression analysis, odds ratio (OR) and 95\% confidence interval (CIs) were calculated. Stepwise Cox analysis allowed us to detect the variables most associated to survival.

\section{Results \\ P-cad expression}

First of all, the paradigmatic P-cad expression was obtained from the standard controls (Fig. 1a): in these, in fact, only a membranous staining was observed at the basal layer of histologically normal oral epithelium; predominantly on the membrane of only a thin line of cells basally located, with occasionally moderate parabasal staining. The intensity of staining for P-cadherin progressively reduced from basal to parabasal layers and stopped in the spinous layer. No staining for P-cadherin was observed in the upper layer.

37 cases (55.2\%) OSCC showed membranous/cytoplasmic positivity for P-cad (Group P-cad +ve)(Table 1), whereas $30(44.8 \%)$ were found negative (Group P-cad ve). When examined the cell staining pattern of positive cases, 25 cases showed a prevalent membranous pattern (Fig. 1b-c), while 12 had a prevalent cytoplasmic pattern (Fig. 1d). Worthy of note, within the Group P-cad +ve, dedifferentiated areas showed both membranous and cytoplasmic P-cad up-regulation: well-differentiated (G1) oral carcinomas showed P-cad up-regulation, while P-cad expression homogeneously reduced in scarcely differentiated oral squamous cell carcinomas (G3), and it shifted to membranous/cytoplasmic co-localization, predominantly cytoplasmic in distribution, or alternatively was absent in a large numbers of cells. Although with these differences in membranous $v$ s cytoplasmic localization of P-cad in OSCC with different G, no statistical association was found between P-cad expression and any variables (age, sex, G, T, N and Stage grouping) considered at baseline. 


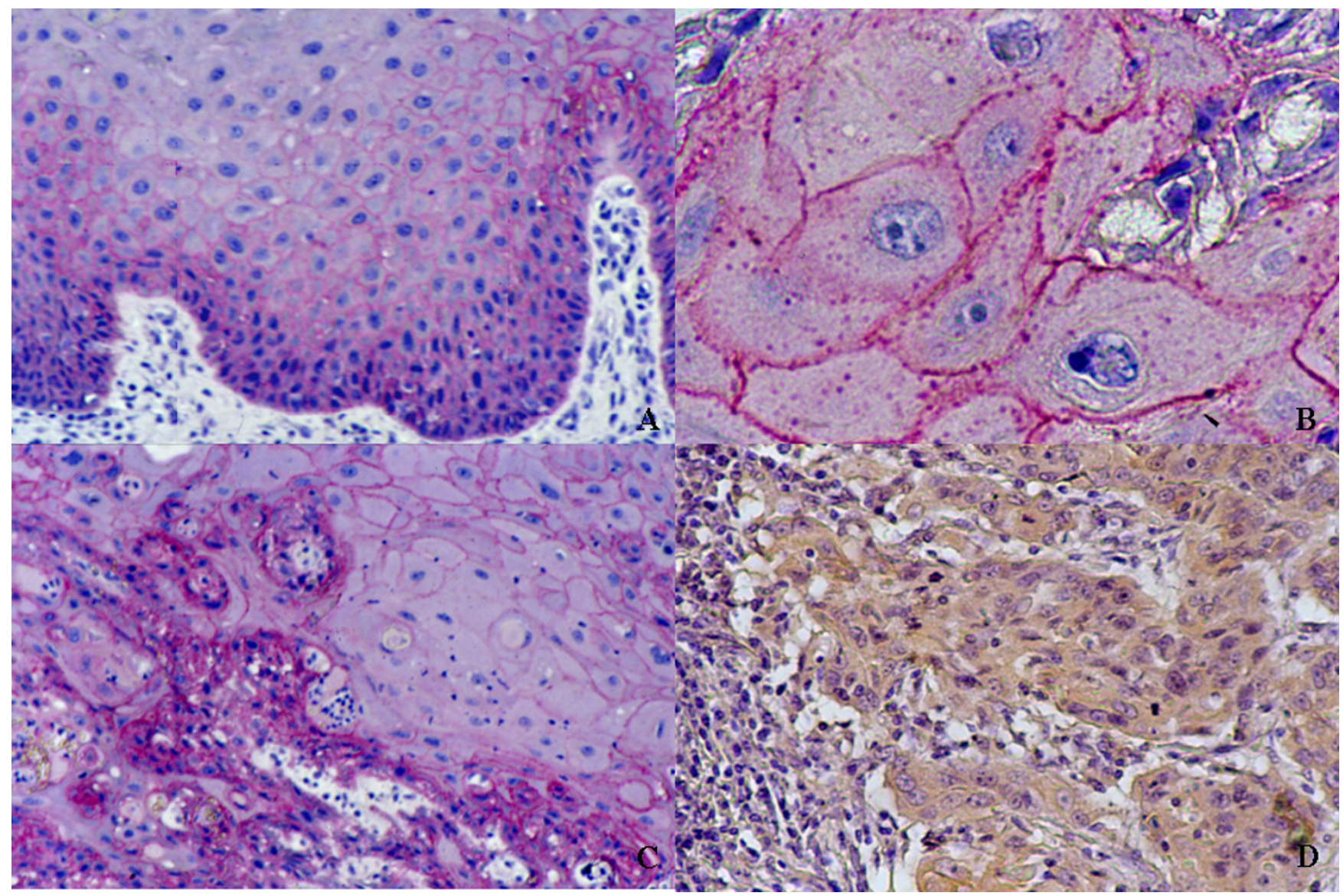

Figure I

a) Strong basal-parabasal membranous expression of P-cadherin in oral hyperplastic epithelium (LSAB-AP, nuclear counterstaining with haematoxylin, $\times 106$ ); b) Membranous P-cadherin expression in oral moderately-differentiated SCC (LASB-AP, $\times 400$ ); c) Membranous expression of P-cadherin in an area of stromal infiltration from moderately-differentiated OSCC (LASB$A P$, nuclear counterstaining with haematoxylin, $\times(60)$; d) Cytoplasmic expression of $P$-cadherin in a case of lowly differentiated OSCC infiltrating stroma (LSAB-HRP, $\times 250$ )

The second part of the analysis planned the study of survival rates with respect to P-cad expression. Although the global disease-specific survival rate at 72 months was 51.0 $\%$, irrespectively of the extent of the tumour or treatment (Fig. 2), the survival rates in the same cohort distributed according to P-cad expression (Group P-cad +ve vs. P-cad -ve) was $79.0 \%$ vs $40.0 \%$ respectively ( $p$-value $=0.04 \mathrm{Log}$ Rank Test). Survival curves stratified according to P-cad expression are illustrated in Fig 3. Still in terms of overall survival, within P-cad +ve group, OSCCs $(\mathrm{n}=12)$ with a prevalent citoplasmic pattern of $\mathrm{P}$-cad showed poorer survival rates than those $(n=25)$ with a prevalent membranous $\mathrm{P}$-cad expression $(\mathrm{P}<0.0001)$. Besides the classic parameters related to survival rate and predictor of a poor outcome (e.g. G, T, N, stage and recurrence), a stepwise model introducing $P$-cad non-expression, without consid- ering recurrence (parameter with the highest OR), showed that also $P$-cad non expression is significantly associated to survival, together with grading and stage. (Table 2, 3).

\section{Discussion}

Both E- and P-cad play a pivotal role in the maintenance of the epithelial structure, even if they are expressed in distinct regions of the epithelium. E-cad is expressed on all epithelial layers, while P-cad is predominantly expressed in the basal layer of stratified squamous epithelia, the proliferative compartment [54-59]. E- and P-cad expression is altered in premalignant and malignant skin tumors, as demonstrated by reduced E-cad and aberrant Pcad expression in human squamous cell carcinomas [59], indicating the importance of coordinated cadherin expression for maintaining normal epidermal structure 
Table I: OSCC grouped by P-cad expression and their features.

\begin{tabular}{|c|c|c|c|c|c|c|}
\hline Variables & No. & P-cad-ve (\%) & P-cad+ve n. (\%) & Mean & $\begin{array}{l}\text { Standard } \\
\text { deviation }\end{array}$ & $P<0.05$ \\
\hline Cases & 67 & $30(44.8)$ & $37(55.2)$ & & & \\
\hline \multicolumn{7}{|l|}{ Age } \\
\hline$</=65$ years & 32 & 16 & 16 & 1.40 & 1.10 & $P=0.363^{\circ}$ \\
\hline$>65$ years & 35 & 14 & 21 & 1.65 & 1.13 & \\
\hline \multicolumn{7}{|l|}{ Sex } \\
\hline Male & 45 & 20 & 25 & 1.55 & 1.07 & $P=0.253^{\circ}$ \\
\hline Female & 22 & 10 & 12 & 1.50 & 1.22 & \\
\hline \multicolumn{7}{|l|}{ Grading } \\
\hline GI & 21 & 6 & 15 & 1.85 & 1.10 & $P=0.143^{*}$ \\
\hline $\mathrm{G} 2$ & 30 & 15 & 15 & 1.53 & 1.07 & \\
\hline G3 & 16 & 9 & 7 & 1.12 & 1.14 & \\
\hline \multicolumn{7}{|l|}{ Staging } \\
\hline 1 & 30 & 10 & 20 & 1,667 & 0,4795 & $P=0,993^{*}$ \\
\hline ॥ & 15 & 6 & 9 & 1,600 & 0,5071 & \\
\hline III & 11 & 7 & 4 & 1,364 & 0,5045 & \\
\hline IV & 11 & 4 & 7 & 1,636 & 0,5045 & \\
\hline
\end{tabular}

'Student-Newmann-Keuls' test.

*One-way Analysis of Variance (ANOVA) and Student-Newman-Keuls Multiple Comparisons Test

[60]. Malignant keratinocytes probably acquire different mechanisms for regulating the expression of these two cadherins [61]. P-cad seems to play a role in the maintenance of the epithelial phenotype and may be involved, together with E-cad, in the final stage of tumor progression in epidermal carcinogenesis, being a marker of hyperproliferative activity [47]. Studies on epidermis [26], gastric epithelium [49], and mammary epithelium [62] showed that P-cad controls cell proliferation in these tissues. P-cad expression seems to be related to tumour progression in gastric [50] and gingival carcinomas [35], while its expression is higher in poorly differentiated than in well-differentiated lung carcinomas [23]. In particular, well-differentiated oral carcinomas showed P-cad expression similar to normal oral mucosa or up-regulated, while $\mathrm{P}$-cad expression homogeneously reduced in low-differentiated oral squamous cell carcinomas or its localization shifted to the cytoplasm, in accordance with other studies on oral mucosa [39] or gastrointestinal mucosa $[48,63]$. Williams et al. (1988) reported a loss of membranous immunostaining at the periphery of the islands of carcinoma with a cytoplasmic immunostaining or a complete loss[39]. In contrast, towards the centre of the islands the more differentiated cells showed mild or moderate membranous staining in well- or moderately-differentiated carcinomas, reflecting the pattern seen in dysplasia [39]. Recently, also in oral premalignant lesions induced in rats it has been found that E-cad and P-cad have similar location of expression as in OSCC and that just P-cad aberrant expression could be a strong marker of carcinogen progression[64].

On the basis of the current knowledge on P-cad and of a previous research conducted by one of the center involved [52], in the present research our main goal was to conduct an in vivo study on the clinical outcome (e.g overall survival rate) of OSCC with respect of quality and quantity of P-cad expression. Hence, in terms of prognostic significance, the lack of P-cad expression $(44.8 \%)$ was found to have an independent association with poorer overall survival rate than P-cad expressing group; moreover, the abnormal (cytoplasmic) expression of P-cad is also associated to a poorer prognosis when compared to that normally membranous. In these latter cases, expression of P-cad shifted to membranous/cytoplasmic colocalisation, predominantly cytoplasmic in distribution, or alternatively was absent from a large numbers of cells. These two main results are consistent with a very recent Italian research [52] in which also other tissues (i.e. lymph node and bone metastases) were investigated.

As regards the lack of P-cad expression, it can be interpreted as a late event prior to invasion, as shown by loss of its expression in dysplasia adjacent to infiltrating 


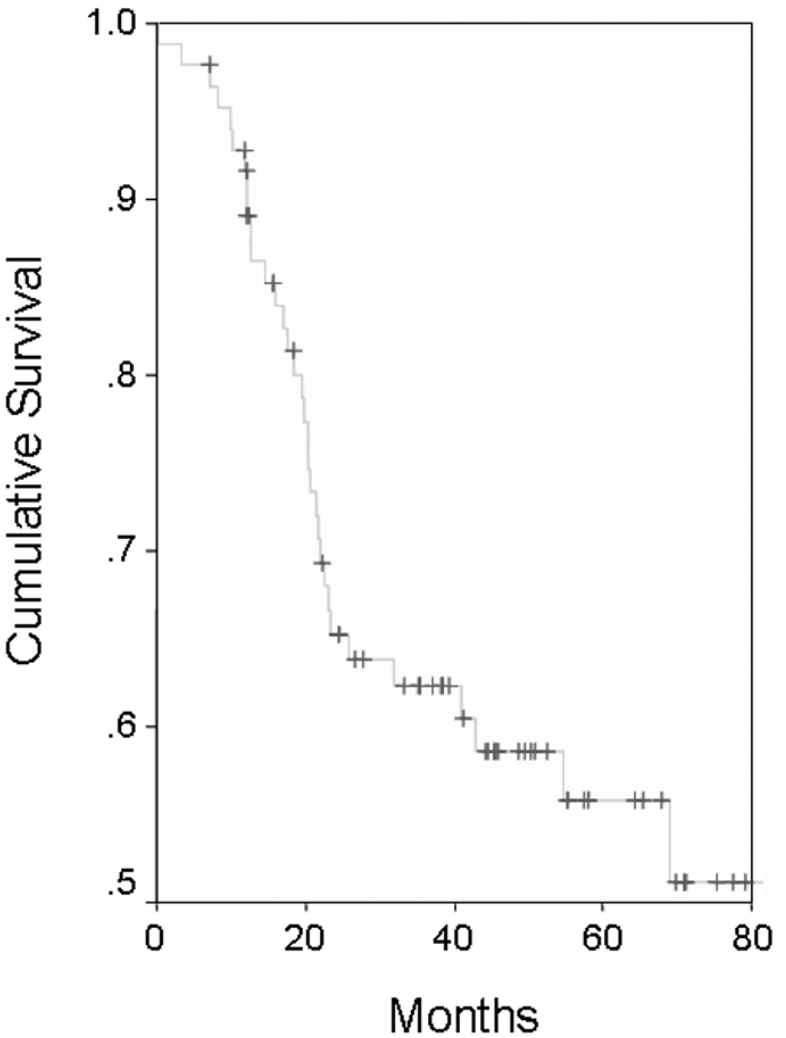

Figure 2

Overall disease-specific survival rate at 72-months (+ censored cases).

carcinomas [39]. The loss of P-cad expression probably comes after P-cad cytoplasmic relocalization. Loss of Pcad expression in OSCC is associated with tumour invasion, while P-cad membranous staining in OSCC is probably due to the up-regulation seen in tumour cell lines and dysplasias. Therefore, in the initial phase of tumour growth the high expression of P-cad may be crucial in the formation of a tumour mass which is ready to progress and metastasize [50]. Whereas anomalous P-cad expression in the spinous layer of epithelium overlying tumour can be a biological marker for keratinocyte atypia and/or premalignant changes[65]. In fact, the continued expression of P-cad in the invasive cells can contribute to the maintenance of the epithelioid phenotype of the carcinoma cells [65]. An experimental study on squamous cell carcinoma cell lines showed aberrant expression in cancer cells, whereas E-cad expression was reduced [61]. SCC cells probably acquire the ability to express $\mathrm{P}$-cad and this molecule plays a role in tumour progression [61]. Elevated $\left[\mathrm{Ca}^{++}\right]$determined increased cell-surface P-cad expression in SCC cell lines by up-regulation of de novo P-cad synthesis, while in normal keratinocytes calcium-

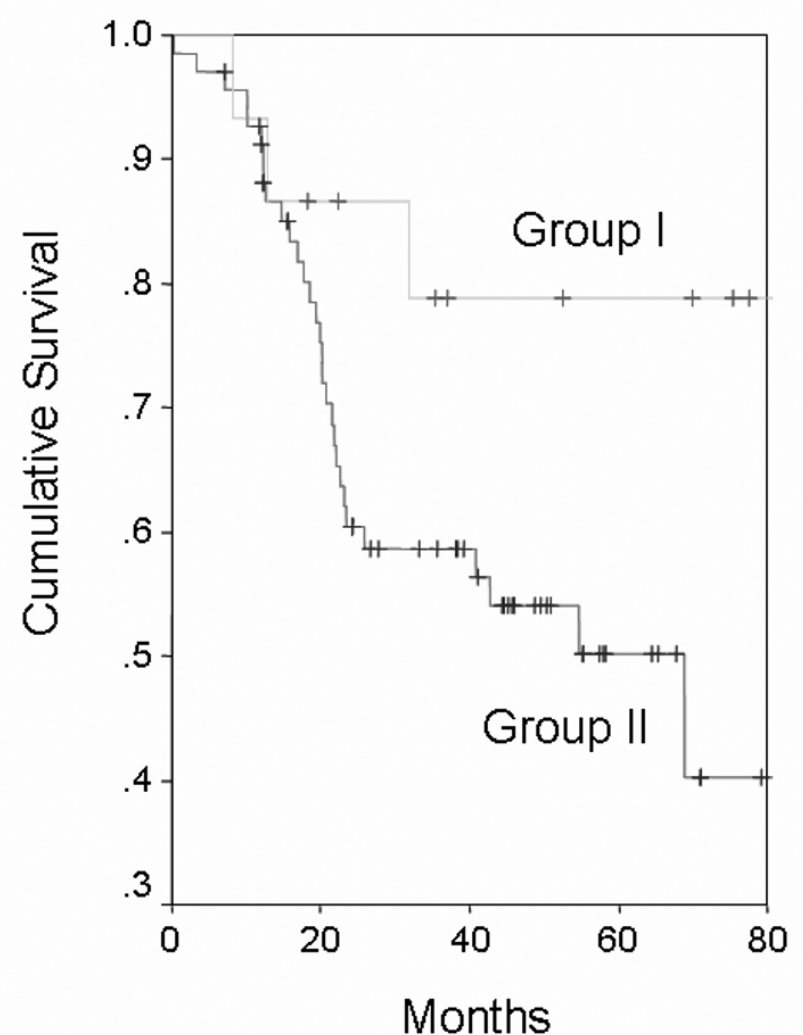

Figure 3

Disease-specific survival rate calculated according to P-cad categories. Log Rank 3.38, I df p-value $=0.0661$ (+ censored cases)

induced cell-surface P-cad expression is a result of the translocation of pre-formed P-cad from the cytosol without up-regulation of P-cad synthesis [60]. These results suggest the existence of a unique mechanism for regulating the P-cad expression gene in tumour cells.

Bagutti et al. (1998) showed no correlation between P-cad expression and differentiation of tumour cells[40], while Sakaki et al. (1994) showed a complete loss of P-cad expression in poorly-differentiated gingival SCC[35]. Cytoplasmic relocalization or loss of P-cad expression may be responsible, together with other known/unknown upregulated oncogenes and downregulated tumour suppressor genes, for the later stages of tumour progression, such as invasive growth and metastasis [50].

On the basis of our present results, no association was found between P-cad expression and any of parameters considered (age, gender, G, T, N, Stage grouping), datum 
Table 2: Cox regression for survival rate with all variables known, apart from $P$-cad.

\begin{tabular}{lcccc}
\hline Variables & OR & & $95 \% \mathrm{Cl}$ & $\mathrm{P}$-value \\
\hline & & Lower & Upper \\
\hline Grading & & 1.292 & 4.241 & .005 \\
$\mathrm{~T}$ & 2.341 & .162 & .940 & .036 \\
$\mathrm{~N}$ & .391 & .062 & .607 & .005 \\
Stage & .194 & 2.327 & 18.456 & .000 \\
Recurrence & 6.553 & 7.697 & 69.745 & .000 \\
\hline
\end{tabular}

Table 3: Cox regression analyses forced for the presence of $P$-cad and without considering recurrence.

\begin{tabular}{lcccc}
\hline Varziables & OR & & $95.0 \% \mathrm{Cl}$ & $\mathrm{P}$-value \\
\hline & & Lower & Upper \\
\hline P-cad & & .964 & 17.172 & .056 \\
Grading & 4.068 & 1.164 & 3.240 & .011 \\
Stage & 1.942 & 1.114 & 1.915 & .006 \\
\hline
\end{tabular}

not consistent with the Italian research cited above [52], probably due to the different sample size.

A limit of the present study could be the fact that assessment of P-cad expression was done according to two scores; a larger sample size is warranted in the future in order to score OSCC in several groups according to P-cad expression with respect to prognosis.

The main present findings, based on overall survival rate, emphasise the role of $\mathrm{P}$-cad expression as an early marker of OSCC prognosis, earlier than recurrence, as being the best marker, unfortunately, detected only after its onset.

\section{Competing interests}

The author(s) declare that they have no competing interests.

\section{Authors' contributions}

LLM conceived of the study, participated in its designcoordination and helped to draft the manuscript. GC participated in the design of the study, helped to analyse data and to draft the manuscript. AF participated in the design of the study and performed the statistical analysis. CS performed immunohistochemical study. RS revised the article critically. GL made substantial contributions to acquisition, analysis and interpretation of data. GP performed immunohistochemical study. ADL performed immunohistochemical study. FC has been involved in drafting the article. All authors read and approved the final manuscript.

\section{Acknowledgements}

This work was supported by a Grant from The Italian MIUR, year 2004.

\section{References}

I. Berenson JR, Yang J, Mickel RA: Frequent amplification of the bcl-I locus in head and neck squamous cell carcinomas. Oncogene 1989, 4(9): IIII-III6.

2. Po Wing Yuen A, Lam KY, Lam LK, Ho CM, Wong A, Chow TL, Yuen WF, Wei WI: Prognostic factors of clinically stage I and II oral tongue carcinoma-A comparative study of stage, thickness, shape, growth pattern, invasive front malignancy grading, Martinez-Gimeno score, and pathologic features. Head Neck 2002, 24(6):513-520

3. P O, Pillai G, Patel S, Fisher C, Archer D, Eccles S, Rhys-Evans P: Tumour thickness predicts cervical nodal metastases and survival in early oral tongue cancer. Oral Oncol 2003, 39(4):386-390.

4. O'Brien CJ, Lauer CS, Fredricks S, Clifford AR, McNeil EB, Bagia JS, Koulmandas C: Tumor thickness influences prognosis of $T I$ and T2 oral cavity cancer--but what thickness? Head Neck 2003, 25(I I):937-945.

5. Lam P, Au-Yeung KM, Cheng PW, Wei WI, Yuen AP, Trendell-Smith $\mathrm{N}, \mathrm{Li} \mathrm{JH}, \mathrm{Li}$ R: Correlating MRI and histologic tumor thickness in the assessment of oral tongue cancer. $A J R A m J$ Roentgenol 2004, 182(3):803-808

6. Lim SC, Zhang S, Ishii G, Endoh Y, Kodama K, Miyamoto S, Hayash R, Ebihara S, Cho JS, Ochiai A: Predictive markers for late cervical metastasis in stage I and II invasive squamous cell carcinoma of the oral tongue. Clin Cancer Res 2004, I0(I Pt I):166-172. 
7. Ross GL, Soutar DS, MacDonald DG, Shoaib T, Camilleri IG, Robertson AG: Improved staging of cervical metastases in clinically node-negative patients with head and neck squamous cell carcinoma. Ann Surg Oncol 2004, I I(2):2 I3-2 I8.

8. Russolo M, Giacomarra V, Papanikolla L, Tirelli G: Prognostic indicators of occult metastases in oral cancer. Laryngoscope 2002. I I 2(7 Pt I): | 320-I323.

9. Sparano A, Weinstein G, Chalian A, Yodul M, Weber R: Multivariate predictors of occult neck metastasis in early oral tongue cancer. Otolaryngol Head Neck Surg 2004, 13 I (4):472-476.

10. Sheahan P, O'Keane C, Sheahan JN, O'Dwyer TP: Effect of tumour thickness and other factors on the risk of regional disease and treatment of the NO neck in early oral squamous carcinoma. Clin Otolaryngol 2003, 28(5):46I-47I.

II. Shear M, Hawkins DM, Farr HW: The prediction of lymph node metastases from oral squamous carcinoma. Cancer 1976, 37(4): $190 \mid-1907$.

12. Frierson HFJ, Cooper PH: Prognostic factors in squamous cell carcinoma of the lower lip. Hum Pathol 1986, 17(4):346-354.

13. Umeda M, Yokoo S, Take Y, Omori A, Nakanishi K, Shimada K: Lymph node metastasis in squamous cell carcinoma of the oral cavity: correlation between histologic features and the prevalence of metastasis. Head Neck 1992, 14(4):263-272.

14. Yamamoto E, Miyakawa A, Kohama G: Mode of invasion and lymph node metastasis in squamous cell carcinoma of the oral cavity. Head Neck Surg 1984, 6(5):938-947.

15. Takeichi M, Hatta K, Nose A, Nagafuchi A: Identification of a gene family of cadherin cell adhesion molecules. Cell Differ Dev 1988, 25 Suppl:9I-94.

16. Gumbiner BM, McCrea PD: Catenins as mediators of the cytoplasmic functions of cadherins. / Cell Sci Suppl I993, I7: I55-I58.

17. Hatta K, Takeichi M: Expression of $\mathbf{N}$-cadherin adhesion molecules associated with early morphogenetic events in chick development. Nature 1986, 320(606 I):447-449.

18. Nose A, Takeichi M: A novel cadherin cell adhesion molecule: its expression patterns associated with implantation and organogenesis of mouse embryos. J Cell Biol 1986, I03(6 Pt 2):2649-2658.

19. Suzuki S, Sano K, Tanihara H: Diversity of the cadherin family: evidence for eight new cadherins in nervous tissue. Cell Regul 1991, 2(4):261-270.

20. Buxton RS, Cowin P, Franke WW, Garrod DR, Green KJ, King IA, Koch PJ, Magee AI, Rees DA, Stanley JR, et al: Nomenclature of the desmosomal cadherins. J Cell Biol 1993, I 2 I (3):48I-483.

21. Hirai Y, Nose A, Kobayashi S, Takeichi M: Expression and role of $E-$ and P-cadherin adhesion molecules in embryonic histogenesis. I. Lung epithelial morphogenesis. Development 1989, 105(2):263-270.

22. Hirai Y, Nose A, Kobayashi S, Takeichi M: Expression and role of $E-$ and P-cadherin adhesion molecules in embryonic histogenesis. II. Skin morphogenesis. Development 1989, 105(2):27I-277

23. Shimoyama $Y$, Hirohashi $S$, Hirano S, Noguchi M, Shimosato $Y$, Takeichi M, Abe O: Cadherin cell-adhesion molecules in human epithelial tissues and carcinomas. Cancer Res 1989, 49(8):2| 28-2।33.

24. Wheelock MJ, Jensen PJ: Regulation of keratinocyte intercellular junction organization and epidermal morphogenesis by E-cadherin. / Cell Biol 1992, I I 7(2):415-425.

25. Lewis JE, Jensen PJ, Wheelock MJ: Cadherin function is required for human keratinocytes to assemble desmosomes and stratify in response to calcium. J Invest Dermatol 1994, 102(6):870-877.

26. Hodivala KJ, Watt FM: Evidence that cadherins play a role in the downregulation of integrin expression that occurs during keratinocyte terminal differentiation. J Cell Biol 1994, 1 24(4):589-600.

27. Birchmeier W, Behrens J: Cadherin expression in carcinomas: role in the formation of cell junctions and the prevention of invasiveness. Biochim Biophys Acta 1994, I 198 ( I): I I-26.

28. Birchmeier W: E-cadherin as a tumor (invasion) suppressor gene. Bioessays 1995, I7(2):97-99.

29. Downer CS, Speight PM: E-cadherin expresson in normal, hyperplastic and malignant oral epithelium. Oral Oncol, Eur Cancer 1993, 29B:303-305.
30. Bowie GL, Caslin AW, Roland NJ, Field JK, Jones AS, Kinsella AR: Expression of the cell-cell adhesion molecule E-cadherin in squamous cell carcinoma of the head and neck. Clin Otolaryngol 1993, I8(3):|96-20|.

3I. Fuller LC, Allen MH, Montesu M, Barker JN, Macdonald DM: Expression of E-cadherin in human epidermal non-melanoma cutaneous tumours. Br J Dermatol 1996, I34(I):28-32.

32. Kinsella AR, Bowie GL, Field JK, Jones AS: Expression of the cellcell adhesion molecule E-cadherin in tongue carcinoma cell lines. J Laryngol Otol 1994, 108(I I):957-96I.

33. Mattijssen V, Peters HM, Schalkwijk L, Manni JJ, van 't Hof-Grootenboer B, de Mulder PH, Ruiter DJ: E-cadherin expression in head and neck squamous-cell carcinoma is associated with clinical outcome. Int J Cancer 1993, 55(4):580-585.

34. Sakaki T, Wato M, Otake S, Shirasu R, Tanaka A: Localization of Ecadherin adhesion molecules in human gingiva and gingival carcinoma. Acta Pathol Jpn 1993, 43(3):99-106.

35. Sakaki T, Wato M, Kaji R, Mushimoto K, Shirasu R, Tanaka A: Correlation of $E$ - and $P$-cadherin expression with differentiation grade and mode of invasion in gingival carcinoma. Pathol Int 1994, 44(4):280-286.

36. Schipper JH, Frixen UH, Behrens J, Unger A, Jahnke K, Birchmeier W: E-cadherin expression in squamous cell carcinomas of head and neck: inverse correlation with tumor dedifferentiation and lymph node metastasis. Cancer Res I99I, 5I(23 Pt I):6328-6337

37. Schipper $\mathrm{JH}$, Unger $\mathrm{A}$, Jahnke $\mathrm{K}$ : E-cadherin as a functional marker of the differentiation and invasiveness of squamous cell carcinoma of the head and neck. Clin Otolaryngol 1994, 19(5):38I-384.

38. Andrews NA, Jones AS, Helliwell TR, Kinsella AR: Expression of the E-cadherin-catenin cell adhesion complex in primary squamous cell carcinomas of the head and neck and their nodal metastases. Br / Cancer 1997, 75(10): 1474- |480.

39. Williams HK, Sanders DS, Jankowski JA, Landini G, Brown AM: Expression of cadherins and catenins in oral epithelial dysplasia and squamous cell carcinoma. J Oral Pathol Med 1998, 27(7):308-317.

40. Bagutti C, Speight PM, Watt FM: Comparison of integrin, cadherin, and catenin expression in squamous cell carcinomas of the oral cavity. J Pathol 1998, 186(I):8-16.

4I. Paul R, Ewing CM, Jarrard DF, Isaacs WB: The cadherin cell-cell adhesion pathway in prostate cancer progression. $\mathrm{Br} J$ Urol 1997, 79 Suppl I:37-43.

42. Soler AP, Harner GD, Knudsen KA, McBrearty FX, Grujic E, Salazar $H$, Han AC, Keshgegian AA: Expression of P-cadherin identifies prostate-specific-antigen-negative cells in epithelial tissues of male sexual accessory organs and in prostatic carcinomas. Implications for prostate cancer biology. Am J Pathol 1997, 15 I (2):47I-478.

43. Shimoyama Y, Gotoh M, Terasaki T, Kitajima M, Hirohashi S: Isolation and sequence analysis of human cadherin-6 complementary DNA for the full coding sequence and its expression in human carcinoma cells. Cancer Res 1995, 55(10):2206-22II.

44. Foty RA, Steinberg MS: Measurement of tumor cell cohesion and suppression of invasion by E- or P-cadherin. Cancer Res 1997, 57(22):5033-5036.

45. Matsuyoshi N, Tanaka T, Toda K, Imamura S: Identification of novel cadherins expressed in human melanoma cells. J Invest Dermatol 1997, 108(6):908-913.

46. Palacios J, Benito N, Pizarro A, Suarez A, Espada J, Cano A, Gamallo C: Anomalous expression of P-cadherin in breast carcinoma. Correlation with E-cadherin expression and pathological features. Am J Pathol 1995, I46(3):605-6/2.

47. Pizarro A, Gamallo C, Benito N, Palacios J, Quintanilla M, Cano A, Contreras F: Differential patterns of placental and epithelial cadherin expression in basal cell carcinoma and in the epidermis overlying tumours. Br J Cancer 1995, 72(2):327-332.

48. Sanders DS, Bruton R, Darnton S], Casson AG, Hanson I, Williams $H K$, Jankowski J: Sequential changes in cadherin-catenin expression associated with the progression and heterogeneity of primary oesophageal squamous carcinoma. Int J Cancer 1998, 79(6):573-579.

49. Shimoyama $Y$, Hirohashi S: Expression of E- and P-cadherin in gastric carcinomas. Cancer Res I991, 5 I (8):2 185-2192. 
50. Yasui W, Sano T, Nishimura K, Kitadai Y, ji ZQ, Yokozaki H, Ito H, Tahara $\mathrm{E}$ : Expression of $\mathbf{P}$-cadherin in gastric carcinomas and its reduction in tumor progression. Int J Cancer 1993, 54(I):49-52.

5I. Rasbridge SA, Gillett CE, Sampson SA, Walsh FS, Millis RR: Epithelial (E-) and placental (P-) cadherin cell adhesion molecule expression in breast carcinoma. J Pathol 1993, I69(2):245-250.

52. Lo Muzio L, Pannone G, Mignogna MD, Staibano S, Mariggio MA, Rubini C, Procaccini M, Dolci M, Bufo P, De Rosa G, Piattelli A: Pcadherin expression predicts clinical outcome in oral squamous cell carcinomas. Histol Histopathol 2004, 19(4): $1089-1099$.

53. Ord RA, Blanchaert RHJ: Current management of oral cancer. A multidisciplinary approach. J Am Dent Assoc 200I, I32 Suppl: 19S-23S.

54. Takeichi M: Morphogenetic roles of classic cadherins. Curr Opin Cell Biol 1995, 7(5):619-627.

55. Borradori L, Sonnenberg A: Hemidesmosomes: roles in adhesion, signaling and human diseases. Curr Opin Cell Biol 1996, 8(5):647-656.

56. Moles JP, Watt FM: The epidermal stem cell compartment: variation in expression levels of E-cadherin and catenins within the basal layer of human epidermis. J Histochem Cytochem 1997, 45(6):867-874.

57. Nicholson LJ, Pei XF, Watt FM: Expression of E-cadherin, P-cadherin and involucrin by normal and neoplastic keratinocytes in culture. Carcinogenesis I99 I, I 2(7): |345-1349.

58. Fujita M, Furukawa F, Fujii K, Horiguchi Y, Takeichi M, Imamura S: Expression of cadherin cell adhesion molecules during human skin development: morphogenesis of epidermis, hair follicles and eccrine sweat ducts. Arch Dermatol Res 1992, 284(3): $159-166$

59. Shirahama S, Furukawa F, Wakita H, Takigawa M: E- and P-cadherin expression in tumor tissues and soluble E-cadherin levels in sera of patients with skin cancer. J Dermatol Sci 1996 I3(I):30-36

60. Wakita $H$, Furukawa $F$, Baba $S$, Takigawa M: Human squamouscell-carcinoma cell line (DJM-I) cells synthesize P- cadherin molecules via an elevation of extracellular calcium: calcium regulates P-cadherin-gene expression at the translationa level via protein tyrosine phosphorylation. Int J Cancer 1997, 73(3):432-439.

61. Wakita H, Shirahama S, Furukawa F: Distinct P-cadherin expression in cultured normal human keratinocytes and squamous cell carcinoma cell lines. Microsc Res Tech 1998, 43(3):218-223.

62. Daniel CW, Strickland P, Friedmann Y: Expression and functional role of $E$ - and P-cadherins in mouse mammary ductal morphogenesis and growth. Dev Biol 1995, 169(2):5II-5I9.

63. Sanders DS, Perry I, Hardy R, Jankowski J: Aberrant P-cadherin expression is a feature of clonal expansion in the gastrointestinal tract associated with repair and neoplasia. J Pathol 2000 , 190(5):526-530.

64. Sakaki T, Tamura I, Kadota H, Kakudo K: Changing expression of $E$ - and $P$-cadherin during rat tongue carcinogenesis induced by 4-nitroquinoline I-oxide. J Oral Pathol Med 2003, 32(9):530-537.

65. Cano A, Gamallo C, Kemp C], Benito N, Palacios J, Quintanilla M, Balmain $A$ : Expression pattern of the cell adhesion molecules. $E$ cadherin, $P$ - cadherin and alpha 6 beta 4 intergrin is altered in pre-malignant skin tumors of p53-deficient mice. Int Cancer 1996, 65(2):254-262.

\section{Pre-publication history}

The pre-publication history for this paper can be accessed here:

http://www.biomedcentral.com/1471-2407/5/63/prepub
Publish with Bio Med Central and every scientist can read your work free of charge

"BioMed Central will be the most significant development for disseminating the results of biomedical research in our lifetime. "

Sir Paul Nurse, Cancer Research UK

Your research papers will be:

- available free of charge to the entire biomedical community

- peer reviewed and published immediately upon acceptance

- cited in PubMed and archived on PubMed Central

- yours - you keep the copyright

Submit your manuscript here:

http://www.biomedcentral.com/info/publishing_adv.asp
BioMedcentral 